\section{Are Zombie Companies in Mexico the same as in the rest of the World?}

\author{
Manuel Humberto De la Garza Cárdenas ${ }^{1}$
}

\begin{abstract}
Purpose - This paper aims to analyze the industry characteristics and the strategic behavior of companies that affect zombie companies.

Theoretical framework - The study was based on the structure-conductperformance paradigm derived from industrial organization theory, because it allows us to explain a firm's results through behavior influenced by external and internal factors.
\end{abstract}

Design/methodology/approach - For the data analysis, the corrected standard errors technique was used on a data set of 99 companies registered in the Mexican Stock Exchange during the period from 2013 to 2017.

Findings - Among the main findings, it is evident that strategic behavior affects zombie companies. On the other hand, we found that market competitiveness negatively affects zombie companies, while barriers to entry positively affect them. The results allow us to identify similarities with and differences from other zombie firms in the world, based on the Latin American environment and its institutional policy.

Practical \& social implications of the research - Zombie firms have a negative connotation; however, they may become necessary to keep businesses operational in developing countries. Also, the study may provide a background to regulations on firm bankruptcy.

Originality/value - The most important contribution is that this is a pioneering investigation that analyzes strategic behavior and its effect on zombie companies. Also, this may be one of the first studies to examine these companies in Latin America, making it possible to identify differences from zombie firms in the rest of the world due to environmental elements such as institutional policy.

Keywords - zombie firms, strategic behavior, industry effect, panel-corrected standard errors.

1. Affliation: Autonomous University of Tamaulipas, School of Commerce and Management, Ciudad Victoria, Mexico.

How to cite:

De la Garza, M. (2021). Are zombie companies in Mexico the same as in the rest of the world? Revista Brasileira de Gestão de Negócios, 23(4), p.635-653.
Received on:

$06 / 19 / 2020$

Approved on:

03/03/2021

Responsible Editor:

Prof. Dr. Eduardo Armando

\section{Evaluation process:}

Double Blind Review

\section{Reviewers:}

Domingo Ribeiro-Soriano; Jordana Marques Kneipp

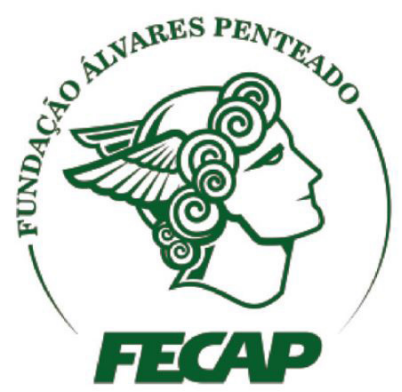

Revista Brasileira de Gestáo de Negócios

https://doi.org/10.7819/rbgn.v23i4.4137 


\section{Introduction}

Zombie firms are organizations that continue to operate through subsidies or support in the form of continuous loans, overvalued projects, or concessions in interest payments (McGowan, Andrews, \& Millot 2017b; Tan, Huang, \& Woo, 2016). The support is given because bankruptcy involves social and economic costs; as a result, official institutions implement protectionist policies and survival actions to protect such firms and avoid these problems (Campa \& Camacho, 2014). This means that zombie firms depend on other institutions because their activities, results, and actions are not sufficient to be able to do without support, thus entering a vicious cycle (Amato \& Fantacci, 2016; Hoshi, 2006; Uchida et al., 2015).

The specialized literature is in an early stage of development. However, there are studies that focus on different countries of the European Union (Urionabarrenetxea, San-Jose, \& Retolaza, 2016), Japan (Caballero, Hoshi, \& Kashyap, 2008), China (Shen \& Chen, 2017; Tan et al., 2016), Spain (Urionabarrenetxea, Garcia-Merino, San-Jose, \& Retolaza, 2018), and different OECD members (McGowan et al., 2017b). The main contribution of these early works was in finding that zombie firms negatively affect the markets because they reduce the attractiveness of an industry by using financial and human resources that regular companies could use (Hoshi, 2006; McGowan et al., 2017b).

Until this point, the literature has focused on economic and financial aspects that give rise to zombie companies, finding that economic shocks encourage their proliferation (Caballero et al., 2008; Hoshi, 2006). It has also been found that a recurring way to support them is through benevolent products such as "evergreen loans" (subsequently known as "zombie loans"). An evergreen loan is a financial product that is continuously renewed by the financier (Uchida et al., 2015). It allows the firm to pay for the debt at lower-than-normal amounts (Broz \& Ridzak, 2017).

Other authors have found that through specific actions such as improving production efficiency or the sale/modernization of obsolete fixed assets, zombie companies can improve their situation (Iwaisako, Fukuoka, \& Kanou, 2013; Nakamura \& Fukuda, 2013; Tan et al., 2016). The results have allowed the literature to focus on operational aspects. Urionabarrenetxea et al. (2016, 2018) found many organizations that persist with this problem regardless of economic crises, arguing that their actions and operations are an essential part of the zombie condition. McGowan et al. (2017a, 2017b) support this, demonstrating the existence of zombie firms in countries such as the United Kingdom, Germany, Austria, and France. There is no reference for economies with severe damage by macroeconomic events. Thus, it is necessary to analyze management aspects because they can complement the understanding of the zombie firms phenomenon.

Considering Latin America, this region represents an attractive environment for these studies. Business management is a complex issue (Maquieira, Preve, \& Sarria-Allende, 2012) and is susceptible to international economic crises (Cabrera, Coronado, Rojas, \& RomeroMeza, 2018). Mexico is a representative market that has been affected by the volatility of international markets and has suffered recent economic crises. Cabrera et al. (2018) show that the macroeconomic environment has a direct impact on the organizations listed on the Mexican Stock Exchange (BMV) and consider the BMV to be an environment where zombie firms can be found.

Historically speaking, the BMV is one of the most recent capital markets among the strongest economies in Latin America. Its creation and development were delayed due to different social, economic, and political factors that Mexico experienced (Moreno-Lázaro, 2015). Also, the BMV has been used abnormally by the State. The State has strongly intervened in it and used it as a financing channel for directing resources, generally to large inefficient firms or for privatizing organizations such as raw material extraction firms (the first companies registered on the BMV). These kinds of firms also received priority and favoritism when allocating financing (Moreno-Lázaro, 2015, 2017). However, as the interventions decreased, industrial companies began to join, and the launch of the BMV took place in the second half of the 20th century, which allowed it to function in a similar way to stock markets in the rest of the world (Moreno-Lázaro, 2015, 2017). The BMV has become one of the most efficient stock exchanges among emerging countries and ranks within the top 25 world stock markets (Cervantes, Montoya, \& Cueto, 2014; Cetorelli \& Peristiani, 2013).

Regarding business management, Mexico presents particularities such as the delay in the implementation of international practices (Kemme \& Koleyni, 2017), protectionist policies towards investors (Juárez, Daza, \& González, 2015), and a high concentration of ownership (Fassler \& Flores Vargas, 2016). These elements of business administration can influence zombie companies. 
Finally, the review of the literature on zombie companies allowed for the identification of a gap in the literature to be addressed in this paper: strategic behavior and how it affects zombie companies. Even though strategic behavior is a central element in administrative sciences, the specialized literature on zombie companies has not studied it sufficiently. On the other hand, it is also pertinent to study industry characteristics, since this is a recurring element in the empirical antecedents. For these reasons, this paper aims to analyze the industry characteristics and the strategic behavior of companies that affect zombie companies. The main contribution of the research is the inclusion of the business strategy variable together with the characteristics of the industry to analyze their respective effects on zombie companies. This contributes to the specialized literature on zombie companies by adding the business strategy perspective that is common in management sciences, but which has not yet been used to study zombie companies. In addition, this research could provide the basis for the future use of new perspectives to study zombie companies.

This paper is structured in five sections starting with this introduction. Section 2 presents the theoretical framework that allows us to understand these companies. Section 3 explains the method used for the statistical analysis. The results are described in Section 4. Section 5 presents the discussion. In the final section, the conclusions are laid out.

\section{Theoretical Framework}

\section{I Zombie firms}

Caballero et al. (2008) defined zombie firms as organizations that receive a subsidy in their financing through interest payment exemptions or concessions. It is not necessarily because they have problems of liquidity or in their operations, however, that they can obtain benefits through this form of subsidy (Lee, 2017). This article uses the Caballero et al. (2008) criterion to identify zombie companies.

Other recurring characteristics are the short-term orientation of operations (Hoshi, 2006; Imai, 2016; Tan et al., 2016), misallocation of resources (Caballero et al., 2008), unproductive assets (Shen \& Chen, 2017), and low productivity (Imai, 2016; McGowan et al., 2017b; Shen \& Chen, 2017). Also, Hoshi (2006) and Urionabarrenetxea et al. $(2016,2018)$ showed that zombie companies tend to be large organizations with greater bargaining power and significant economic value, which is why creditors prefer to offer less strict conditions.

Another feature is that there are non-competitive or highly state-controlled industries, which favor the existence of these companies (Caballero et al., 2008). This characteristic is due to the sector favoring the permanence of stagnant companies by promoting their passivity instead of pressuring them to evolve to compete (Caballero et al., 2008; Fukuda \& Nakamura, 2011; McGowan et al., 2017b).

Regarding the effects of zombie firms on the markets, Caballero et al. (2008), Fukuda and Nakamura (2011), and Hoshi (2006) mention that they restrict the competitiveness of an industry by avoiding a process of creative destruction and they compete for factors of production such as labor and capital, thus obstructing healthy organizations.

The literature shows that there are elements of a firm's industry and operational characteristics that lead to a zombie situation. For this reason, this paper uses the structure-conduct-performance (SCP) paradigm as an analytical framework to determine the industry characteristics and the strategic behavior that affect zombie firms.

The SCP paradigm defines companies as complex organisms, made up of a set of elements, mechanisms, and articulated intentions to achieve sustainable and viable operations (Miles, Snow, Meyer, \& Coleman, 1978). Furthermore, organizations interact with others to carry out their activities; thus, behaviors aimed at adapting to their environment are influenced by the characteristics of the company and the industry (Hall \& Saias, 1980; Miles et al., 1978).

However, a company's configuration is limited by its preferences and control over its resources and structure (Albertos \& Kuo, 2018), which indicates that strategic behavior depends on the environmental perception and the own resources and capacities. The SCP paradigm analyzes the characteristics of an industry and the actions carried out by companies to understand organizations (Bain, 1968; Mason, 1939). Therefore, the behavior of companies and the industry in which they operate will be analyzed below. 


\subsection{Firm behavior}

A firm's behavior is defined by "strategic choices" that are made based on the perceptions of the manager(s) (Caves, 1980; Miles et al., 1978). This behavior is strategic because it includes articulating policies, actions, and resources to achieve the established goals, objectives, and mission (Rumelt, Schendel, \& Teece, 1991). Based on them, firms make adaptations, acquire forms, or assume positions to survive (Caves, 1980; Ghemawat, 2002).

Some authors have developed different categories of firm strategic behavior, such as the generic strategies of Porter (1996) or the Miles et al. (1978) typology, which summarize how a firm competes and obtains better returns compared to its competitors (Porter, 1980) or defines how to act to survive in a market (Miles et al., 1978).

The classifications of Miles et al. (1978) and Porter (1980) are consistent with each other. Both are recognized, tested, and accepted models of strategic behavior, applicable to different environments (Higgins, Omer, \& Phillips 2015). Figure 1 represents strategic behavior as a continuous line with defensive behavior at one end and proactive behavior at the other.

In relation to the empirical evidence, there is no consistency in the results. On the one hand, Nakamura and Fukuda (2013) showed that companies that choose to be cost-efficient improve their situation, while proactive efforts do not have a favorable effect on the zombie condition. Urionabarrenetxea et al. (2018) found that knowledge-intensive companies are more likely to be zombie companies. On the other hand, Shen and Chen (2017) showed that stagnant companies, with no interest in operational improvement, shy away from innovation, technology, and proactivity. However, Lee (2017) argued that investing in $\mathrm{R} \& \mathrm{D}$ is an effective way to abandon the zombie company category. The studies that support the relationship between proactive strategic behavior and zombie companies argue that these companies are based on projects or activities that require greater financial investment and therefore have greater risk, which means that if the activities fail or encounter some difficulties, fulfilling the obligations will be difficult.

Since empirical studies on zombie companies are scarce, the decision was taken to use studies that associate strategic behavior with the probability of failure (Li \& Liu, 2009; Pereira \& Jardim, 2013). Jermias (2008) and Simerly and Li (2000) found a higher probability of not meeting financial obligations in proactive companies than in cost-efficient ones, supporting the argument above. OrtizVillajos and Sotoca (2018) found a positive relationship between proactive behavior and bankruptcy risk.

On the other hand, Bentley, Omer, and Sharp (2013) empirically argued that proactive companies have better control over their finances; thus, the probability of bankruptcy is lower. Along these lines, Vicente-Lorente (2001) explained that investments in this type of company are particular; therefore adequate implementation will facilitate debt compliance. Nogueira, Fernández-López, Calvo, and Rodeiro-Pazos (2018) added that these companies maintain a smaller amount of idle assets and they use most of their financial resources for production. As a result, the following hypothesis is presented:

\section{H1: Strategic behavior affects zombie companies.}

\section{$2 \cdot 3$ Industry characteristics}

According to the SCR paradigm, industries present characteristics that influence the companies in

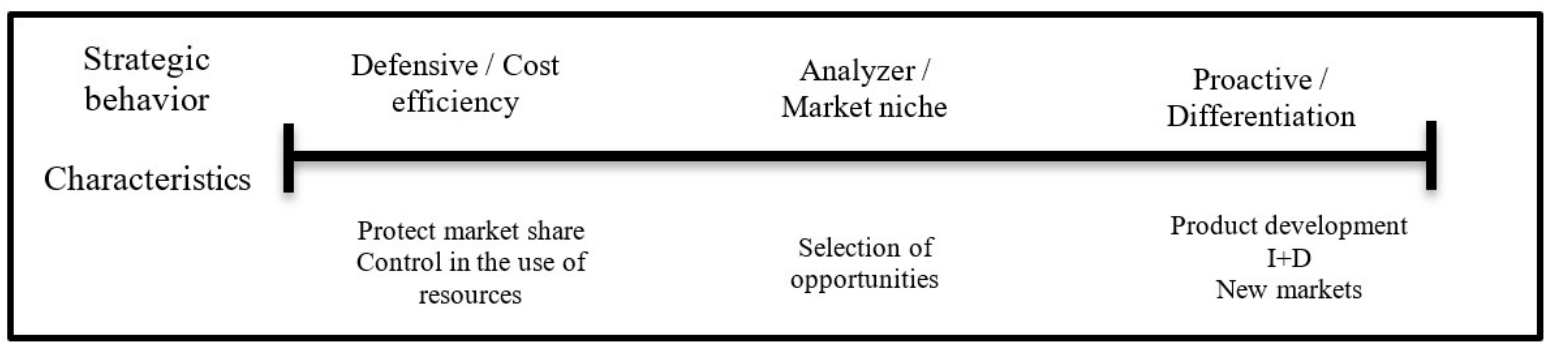

Figure 1. Vision of strategic behavior from Anwar and Hasnu (2016) and Miles et al. (1978)

Note. Adapted from "Business strategy and firm performance: A multi-industry analysis." Anwar and Hasnu, Journal of Strategy and Management, 9(9), 2016; "Organizational strategy, structure, and process. Academy of management review." Miles, Snow, Meyer, \& Coleman. Academy of Management, 3(3), 1978. 
them and their results, such as quantity supplied and demanded, elasticity, inflation rate, and economic cycle. Other factors include the characteristics of the product, the degree of technology, the level of innovation, the availability of materials, and the life cycle of the product (Shapiro, 1989; Sheel, 2016). Caballero et al. (2008) and Hoshi (2006) found a greater presence of zombie companies in specific sectors, suggesting that industry characteristics influence these organizations.

Industries differ. The companies in them tend to be structurally different from those in different sectors (Ohlson, 1980). Thus, each industry has specific characteristics that have a particular influence on each company (Mohammed, Ismail, \& Muhammad, 2015; Ren, Hu, \& Cui, 2018). Shocks, such as innovations or regulations, change market structures and conditions, which cause changes in organizations (Demsetz, 1973).

Among these characteristics, one of the most influential is the level of market competitiveness (Levin, Cohen, \& Mowery, 1985), which refers to the ability of units to rival each other in a given market (Gutiérrez Rodríguez \& Almanza, 2016). Cool, Dierickx, and Jemison (1989) and Martin (1983) use market share as a simple way to know the level of competitiveness of the industry (Keil, 2017). Market share refers to the portion of total sales made in the industry that correspond to a company (Schmalensee, 1989), and it is related to the degree of market concentration (Bain, 1968; Cool et al., 1989; Mueller, 1983).

There is an inverse association between the degree of concentration and market competitiveness, since organizations with a large share will have "market power" and more significant influence on the industry, negatively affecting the rest of the market by restricting the ability of other firms to compete (Boulding \& Staelin, 1990; Edeling \& Himme, 2018). Regarding market competitiveness, Ailawadi, Farris and Parry (1999) and Jacobson (1988) found that organizations with high "market power" tended to negotiate better terms with their trading partners by developing more beneficial relationships, such as in the case of zombie companies.

Boulding and Staelin (1993) mention that business success can cause organizations to lose interest in taking other types of actions that improve profitability. They called such businesses "fat and happy," describing this as a kind of stagnation or passivity regarding the development and evolution of the organization (Edeling \& Himme, 2018). Keil (2018) argues that business comfort can arise from a lack of competition in the market. It can be concluded that the case described by Boulding and Staelin (1993) is similar to the characteristics of zombie companies, because Caballero et al. (2008), Fukuda and Nakamura (2011), and Shen and Chen (2017) showed that an industry with greater competition has fewer zombie organizations, explaining that concentrated sectors are conducive to the existence of these firms.

Since studies on zombie companies are limited, the decision was taken to review articles that study the effect of an industry's level of competitiveness on companies. Mueller (1983) showed empirical evidence that a higher market concentration negatively affects organizations, as did Keil (2018), Khan, Ahmad, and Gee (2016), and Martin (1983). Noman, Gee, and Isa (2017) showed that a higher market concentration increases the risk of bankruptcy, and Edeling and Himme (2018) specify that it is more significant in developing countries.

However, other studies have found that market concentration benefits organizations (Gallagher, Ignatieva, \& McCulloch; Khan, 2016; Lee \& Yang, 2016). The metaanalysis by Szymanski, Bharadwaj, and Varadarajan (1993) concludes that market share is, on average, $20 \%$ related to company performance. Based on the empirical review presented, the following hypothesis is presented:

\section{H2: A higher level to market competi- tiveness discourages zombie firms.}

Another influential factor in industries is the degree of barriers to entry (Ellickson, 2015), which is the difficulties that new competitors have in entering a market (Ho, 2015). Another way of looking at them is as the costs associated with entering a market (Kimenyi Lee, \& Shughart, 1990). According to Bain (1968), they act as a filter for companies willing to compete (Mueller, 1983).

Barriers to entry can be structural or behavioral (Hsu, Tsai, \& Yang, 2008). The first relate to the idiosyncratic nature of the market, which means the companies' specific capacities or resources to compete. Some examples are the initial amount of investment required (Ma, Weng, \& Yu, 2015; Wernerfelt \& Montgomery, 1988), the specificity and technification of the products offered, the types of assets needed for the production process (Stiegert, Wang, $\&$ Rogers, 2009), or the type of regulations (Hsu et al., 2008).

The second classification refers to the companies' actions, such as strategies that will force new competitors to match them if they wish to enter or remain in the 
market (Stiegert et al., 2009). These include investments in marketing (Stiegert et al., 2009), economies of scale (Bain, 1968; Ho, 2015; Ma et al., 2015; Porter, 1980), and the level of product differentiation (Mueller, 1983).

Regarding the empirical evidence, Christmann, Day, and Yip (1999) find that the level of barriers to entry is positively and significantly related to business performance. Authors such as Kimenyi et al. (1990), Schivardi and Viviano (2011), and Yao, Song, and Song (2018) confirm this relationship. On the other hand, Collard-Wexler (2014) showed that barriers to entry hurt market performance, as did Lee and Yang (2016). Tong and Saladrigues (2018) showed a similar relationship with the probability of business survival in Spain. D. McGowan (2014) found that a higher level of barriers to entry helps avoid creative destruction processes; in other words, they encourage inefficient companies to remain in the market. Similar results are offered by Maican and Orth (2018) in the food sector in Sweden. Based on the empirical review presented, the following hypothesis is proposed:

\section{H3: A higher level of barriers to entry encourages zombie firms.}

\section{Method}

\section{I Sample selection and data collection}

The sample selected for this paper was composed of firms listed on the BMV between 2013 and 2017. Of the 147 companies listed for statistical analysis, 27 financial firms were eliminated because of the difficulty of comparing them with the others. Of the remaining 120 companies, 21 were removed that did not meet the zombie company criterion, which will be explained later. The final sample consisted of a total of 99 firms. The data source was the annual reports published by the BMV.

\subsection{Research variables}

For zombie firms, the method developed by Hoshi (2006) known as EIR was used, which calculates the extent to which the actual interest payment $(\mathrm{R})$ exceed the minimum required interest payment $\left(\mathrm{R}^{*}\right)$. Minimum interest payments are a hypothetical preferential cost of debt and Caballero et al. (2008) defined the formula as follows:

$$
R_{i, t}^{*}=\left(r S_{t-1} \cdot B S_{i, t-1}\right)+\left(\left(\frac{1}{5} \sum r l_{t, j}\right) \cdot B L_{i, t-1}\right)
$$

BS represents short-term liabilities minus accounts payable and taxes payable; BL is long-term liabilities; rs represents the average short-term interest rate; $\mathrm{rl}$ is the average long-term interest rate (the interest rate taken as a reference was CETES, which are debt instruments issued by the government and which have a preferential cost). Afterwards, it is necessary to compare $\mathrm{R}$ * with respect to $\mathrm{R}$ using the following formula:

$E I R=\frac{R_{i, j}-R_{i, j}^{*}}{\frac{R_{i, j}+R^{*}}{2}}$

EIR takes values between -2 and 2 , with zombie companies falling on the negative side, while non-zombie companies are on the positive side. It is necessary to say that the measurement may be wrong and healthy companies that deserve preferential conditions or firms that generate enough profits to pay debt quickly could be placed in the zombie category. However, Hoshi (2006) analyzes the effectiveness of his method, concluding that it is adequate, and he dismissed the probability of error as being very low.

Despite this, to reduce the probability of error, the decision was taken to apply the criteria of Fukuda and Nakamura (2011), who compared the generation of profits of a company with respect to the hypothetical cost of debt, defining that those that generate profits higher than interest cannot be zombies, that is, EBITDA $>\mathrm{P}^{*}$. Because of this, it was decided that companies that meet this condition would be removed to avoid measurement errors.

For strategic behavior, the scoring method is applied (Evans \& Green, 2000; Smith Guthrie, \& Chen, 1986), based on financial information. In this paper, strategic behavior is formed of four measures that represent actions related to the way a company behaves in its industry. Each quantification allows the identification of different strategic behaviors. For example, a proactive company must have a greater orientation towards innovation (see Table 1).

Consequently, as Evans and Green (2000) proposed, each company was ranked from weakest to strongest for each indicator using a quintile ranking. Finally, points between 0 and 4 were awarded according to the quintile achieved ( 0 for the lowest quintile and 
Table 1

\section{Dimensions that define strategic behavior}

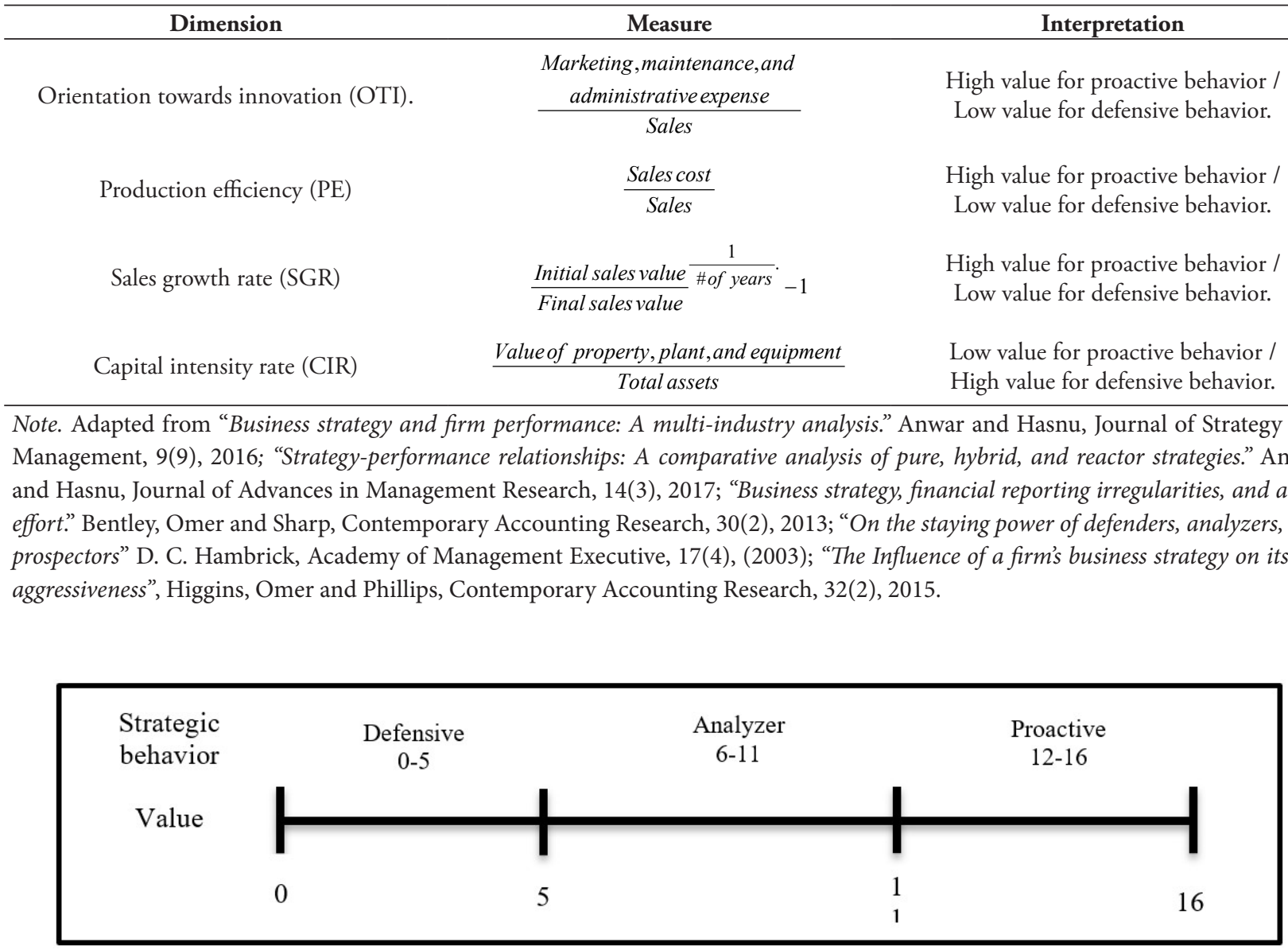

Figure 2. Strategic behavior values

4 for the highest), where it should be clarified that the score is inverse for CIR. This way, a proxy was obtained that represents the strategic behavior, where, as its value increases, the company will be more proactive; otherwise, it represents defensive behavior (see Figure 2).

For market competitiveness, relative market share is used (Li, Nie, Zhao, \& Li., 2017; Martin, 1983; Wu, Gao, \& Gu, 2015). Market share is a measure that shows the portion that each company represents in a particular sector (Szymanski et al., 1993; Varadarajan \& Kaul, 2018).

Market share $=\frac{X i j}{X j}$

$\mathrm{Xij}_{\mathrm{ij}}$ represent the sales of firm $\mathrm{i}$ in industry $\mathrm{j}$ and $\mathrm{Xj}$ means the sales of industry $j$. The result is multiplied by -1 because the market share is an inverse measure for market competitiveness; in other words, a higher (lower) concentration implies less (more) competitiveness.

For barriers to entry, the measure selected was the level of capital investment needed to compete (Ma et al., 2015; Wernerfelt \& Montgomery, 1988) According to Wernerfelt and Montgomery (1988), this represents the capital needed to enter an industry, and helps identify the organizations that exercise the most power in the sector in which they operate. The following formula was used to calculate the variable:

Investment cost $=\frac{(C C i j)}{(P i j)}$

CCij represents the stockholders' equity of company $\mathrm{i}$ in industry $\mathrm{j}$ and $\mathrm{Pij}$ is the production or sales value of company $\mathrm{i}$ in industry $\mathrm{j}$. As the cost of investment 
increases, it shows that a higher amount of capital will be required to obtain a unit of production, that is, a high level of barriers to entry. As for low values, this shows a lower level of barriers to entry, indicating that firms require less capital investment for a given level of production.

The nature of the zombie company variable is inverse, which means that a higher zombie situation implies a higher negative value. The results can be confusing, so to facilitate their interpretation, Table 2 shows the alignment between the hypothesis and the sign expected to support it.

In summary, a positive impact on the dependent variable in this case will be represented by a negative sign of the parameter. A more in-depth description of the various measurements found in no Appendix.

\subsection{Data analysis}

For the statistical analysis, the STATA software was used on a data panel. According to Cameron and Trivedi (2010), the database forms a short $(\mathrm{N}>\mathrm{T})$ and balanced panel with 99 companies over five years. The Breusch-Pagan test (p-value of 0.000) and the Pesaran test for short panels (Pesaran, 2004) confirmed that the panel data model was preferable to a data pool (Hoyos \& Sarafidis, 2006). Consequently, the Hausman test ( $p$-value of 0.000 ) indicated that the fixed effects model was better than the random effects one for this study. Next, autocorrelation and heteroscedasticity were evaluated using the Wooldridge test ( $\mathrm{p}$-value of 0.6299) and Wald test ( $\mathrm{p}$-value of 0.000). These tests evidenced that the panel shows heteroscedasticity, forcing the use of alternatives for the panel data analysis.

Following the recommendations of Beck and Katz (1995), Gujarati and Porter (2004), and Reed and Ye (2011), I opted for a panel data analysis using OLS with panel-corrected standard errors (PCSE). According to Alabede (2018), Bailey and Katz (2011), Millo (2017), and Yahya and Ghazali (2017), PCSE produce more accurate estimates in heteroscedastic panels, including short panels, for hypothesis testing. The econometric model takes the following form:

$$
\begin{aligned}
& \text { Zombie firm }_{i t}=\beta+\beta \text { Strategic behavior } \\
& \text { - }
\end{aligned}
$$

The standard errors corrected for panel heteroscedasticity are obtained as the square roots of the diagonal elements of the matrix:

$$
\operatorname{cov}(\beta)=\left(X^{T} X\right)^{-1}\left(X^{T}(\Phi . I T) X\right)\left(X^{T} X\right)^{-1}
$$

where $\Phi$ is an $\mathrm{N} \times \mathrm{N}$ matrix with the element $(\mathrm{i}, \mathrm{j})$ estimated by:

$$
\Phi=\frac{\left.\sum \mathrm{t} T=1 \text { êi, têj, t }\right)}{T}
$$

\section{Results}

The first thing to note is that of the 99 companies, $38 \%$ were zombie companies in at least one of the years studied. Table 3 shows the number and percentage of zombie companies in each sector included in the study. What stands out the most is that the industries with the highest propensity for these companies (without considering the energy sector) are telecommunications, the health sector, and the industrial sector.

Another analysis is the comparison between the zombie and non-zombie firms in each sector. The values of the means are compared between the groups, resulting in significant differences in strategic behavior and barriers to entry. Table 4 breaks down the means of the groups divided by sector, and it shows that, in most sectors, zombie companies have more proactive strategic behavior than those that are not classified as zombies. Furthermore, these firms monopolize the market in which they participate and have barriers to limit the entry of new competitors.

Table 2

Alignment of hypotheses with the measurement variables

\begin{tabular}{cccc}
\hline Variable & Hypothesis/Effect & Measure & $\begin{array}{c}\text { Sign that supports the } \\
\text { hypothesis }\end{array}$ \\
\hline Strategic behavior & Positive/Negative & Strategic behavior proxy & $+/-$ \\
Market competitiveness & Negative & Relative market share & $+{ }^{1}$ \\
Barriers to entry & Positive & Investment cost ratio & - \\
\hline
\end{tabular}

Note. ${ }^{1}$ to emphasize that the measurement was multiplied by -1 to align it to the variable it represents. 
Table 3

\section{Distribution of zombie companies by BMV sectors}

\begin{tabular}{cccc}
\hline Sector & Zombie Firms & Total Firms & Percentage \\
\hline Energy & 1 & 1 & $100 \%$ \\
Industrial & 14 & 31 & $45 \%$ \\
Material & 8 & 22 & $36 \%$ \\
Telecommunications & 4 & 7 & $57 \%$ \\
Health & 2 & 4 & $50 \%$ \\
Frequent Consumption & 2 & 16 & $12.5 \%$ \\
Non-Frequent Consumption & 7 & 18 & $38.9 \%$ \\
Total & 38 & 99 & $38.9 \%$ \\
\hline
\end{tabular}

Note. The sectors contemplated are those defined by the BMV.

Table 4

Comparative analysis between zombie and non-zombie firms.

\begin{tabular}{|c|c|c|c|c|c|c|}
\hline \multirow{2}{*}{ Industry } & \multicolumn{2}{|c|}{ Strategic behavior } & \multicolumn{2}{|c|}{ Market competitiveness } & \multicolumn{2}{|c|}{ Barriers to entry } \\
\hline & Non-Zombie & Zombie & Non-Zombie & Zombie & Non-Zombie & Zombie \\
\hline Energy & 5 & 8.25 & 1 & 1 & 2.8332 & 3.0332 \\
\hline Industrial & 7.95 & 10.55 & 0.0185 & 0.0398 & 1.3688 & 1.275 \\
\hline Material & 6.31 & 8.45 & 0.0324 & 0.052 & 0.7569 & 1.086 \\
\hline $\begin{array}{c}\text { Frequent } \\
\text { Consumption }\end{array}$ & 7.41 & 9.96 & 0.0417 & .0632 & 0.5958 & 0.5123 \\
\hline Health & 8.87 & 8.25 & 0.2473 & 0.2499 & 0.5141 & 0.8912 \\
\hline Telecommunications & 7.72 & 9.38 & 0.1251 & 0.1516 & 0.6858 & 0.8595 \\
\hline $\begin{array}{l}\text { Non-Frequent } \\
\text { Consumption }\end{array}$ & 7.2 & 10.52 & 0.1876 & 0.0824 & 0.91008 & 1.5046 \\
\hline
\end{tabular}

Note. The values correspond to the average of the variable by sector

Table 5

\section{Data panel analysis results.}

\begin{tabular}{|c|c|c|c|c|}
\hline & Model 1 & Model 2 & Model 3 & Model 4 \\
\hline Strategic Behavior & 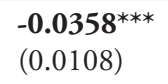 & $\begin{array}{l}-\mathbf{- 0 3 5 8}^{\text {*** }} \\
(0.0106)\end{array}$ & $\begin{array}{l}\mathbf{- 0 . 0 2 7 9}^{* *} \\
(0.0106)\end{array}$ & $\begin{array}{l}-\mathbf{0 . 0 2 8 0 4} 4^{* * *} \\
(0.104)\end{array}$ \\
\hline Market Competitiveness & $\begin{array}{c}0.1179 \\
(0.2161)\end{array}$ & $\begin{array}{c}0.1217 \\
(0.1254)\end{array}$ & $\begin{array}{l}\mathbf{0 . 4 0 3 1}^{\text {****}} \\
(0.1068)\end{array}$ & $\begin{array}{l}\mathbf{0 . 4 0 3 9}^{* * *} \\
(0.1059)\end{array}$ \\
\hline Barriers to Entry & $\begin{array}{l}-0.0557 \\
(0.0151)\end{array}$ & $\begin{array}{c}0.0097 \\
(0.0359)\end{array}$ & $\begin{array}{l}\mathbf{0 . 1 0 8 2}^{* *} \\
(0.0482)\end{array}$ & $\begin{array}{l}\mathbf{0 . 0 1 0 4 0}^{* *} \\
(0.0468)\end{array}$ \\
\hline Constant & $\begin{array}{l}\mathbf{0 . 4 8 0 1}^{\text {**** }} \\
(0.1723)\end{array}$ & $\begin{array}{l}\mathbf{0 . 5 2 9 6}^{* * *} \\
(0.1728)\end{array}$ & $\begin{array}{l}-\mathbf{0 . 9 9 8 9 * * *} \\
(0.2984)\end{array}$ & $\begin{array}{l}-\mathbf{0 . 9 3 5 7 * * *} \\
(0.2909)\end{array}$ \\
\hline Firm Age & & $\begin{array}{l}-\mathbf{0 . 0 0 0 8}^{\text {****}} \\
(0.0002)\end{array}$ & & $\begin{array}{l}-\mathbf{0 . 0 0 0 8}^{* *} \\
(0.0002)\end{array}$ \\
\hline Firm Size & & & $\begin{array}{l}\mathbf{0 . 0 6 9 8}^{* * *} \\
(0.01437)\end{array}$ & $\begin{array}{l}\mathbf{0 . 0 6 9 1}^{* * *} \\
(0.014)\end{array}$ \\
\hline $\mathrm{R}^{2}$ & 0.1203 & 01252 & 0.1314 & 0.173 \\
\hline Model Sig. & $\begin{array}{c}73.77^{* * *} \\
(0.000)\end{array}$ & $\begin{array}{r}73.37^{* * *} \\
(0.0000)\end{array}$ & $\begin{array}{r}\mathbf{1 4 0 . 3 5}^{\text {****}} \\
(0.0000)\end{array}$ & $\begin{array}{c}\mathbf{1 4 4 . 0 4}^{* * * *} \\
(0.000)\end{array}$ \\
\hline
\end{tabular}

Note. Each column reports the coefficient estimates and their standard errors in parentheses. Heteroscedasticity-robust standard errors were used in each regression. ${ }^{* *}$ Significance level of $10 \%{ }^{* *}$ Significance level of $5 \%{ }^{*}$ Significance level of $1 \%$. 
Table 6

Hypothesis test.

\begin{tabular}{|c|c|c|}
\hline Hypothesis & Result & H0 rejection \\
\hline H1: Strategic behavior effects on zombie companies. & $-0.028^{* * *}$ & Yes \\
\hline H2: A higher level of market competitiveness discourages zombie firms. & $0.4039^{* * *}$ & Yes \\
\hline H3: A higher level of barriers to entry encourages zombie firms. & $0.0104^{* *}$ & No \\
\hline
\end{tabular}

Note. The zombie company measure is negative, thus a negative coefficient means that the zombie situation is deepened or enhanced. ${ }^{* * *}$ Significance level of $10 \%{ }^{* *}$ Significance level of $5 \% *$ Significance level of $1 \%$.

Finally, the result of the inferential analysis is presented in Table 5. Four models were run to include two control variables (age of the company and size of the company). Model 1 only includes the study variables, while model 2 and model 3 have one of the control variables. Model 4 is complete and includes all the variables.

The different models present statistical significance and show consistency for the signs and values of the coefficients. Likewise, the $\mathrm{R}^{2}$ values are around $15 \%$, which are similar to in the empirical studies of Fukuda and Nakamura (2011), Imai (2016), and McGowan et al. (2017b), who show coefficients of between 0.02 to 0.07 , while Jiang, Li, and Song (2017) and Shen and Chen (2017) obtained values between 0.14 and 0.2036 by including variables of an operational nature.

It should be noted that the gap in the literature is not only related to investigating zombie companies in Latin America, but also to including the perspective of the organization's behavior, which could shed light on the phenomenon. For this reason and considering the objective of the paper (to analyze the characteristics of the industry and the strategic behavior of companies that affect zombie companies), the result for each variable will be reviewed.

Regarding strategic behavior, H1 (strategic behavior affects zombie companies) is supported by the empirical result (Fukuda \& Nakamura, 2011; Shen \& Chen, 2017; Urionabarrenetxea et al., 2016). However, beyond checking the statistical significance, the direction of the effect on zombie companies is positive, which agrees with the studies that maintain that companies prioritize operational efficiency to improve the zombie situation. The result obtained shows that if a company moves away from the efficiency approach, it will get closer to the zombie situation.

To better understand this, it is necessary to finish the review of the result. Regarding H2, this is supported by the empirical result because the coefficient has a negative and significant effect, which means that the existence of more and better competitors in an industry negatively affects zombie companies, which is consistent with previous literature and empirical studies (Caballero et al., 2008; Fukuda \& Nakamura, 2011; Shen \& Chen, 2017). It is worth mentioning that Khan et al. (2016) and Khan, Ahmad, and Chan (2018) showed opposite results, arguing that organizations that are in uncompetitive markets tend to perform better and have better capabilities to function in these sectors.

H3 (a higher level of barriers to entry encourages zombie firms) is not supported by the result obtained, despite it being statistically significant. The direction of the effect is the opposite; that is, in the Mexican context, barriers to entry help to prevent these types of companies. The results indicate that low barriers to entry prevent the presence of zombie companies. Finally, Table 6 summarizes the hypotheses with their respective statistical results as analyzed in this section.

\section{Discussion}

Before starting the paper's discussion, it is worth mentioning that the study is limited to Mexico. The firms in the BMV are many of the most valuable companies in the country. However, this does not mean that they are the most competitive since the State has used this institution as a mechanism to channel investments. Another point to highlight is that the period considered for the study represents a period of economic stability for the country, which shows a clearer effect of the variables studied (Moreno-Lázaro, 2015, 2017).

The results obtained in this research suggest that zombie companies in Mexico are different from those initially described in the literature. First, it was found that zombie firms were the result of economic and financial crises; thus, they received help to avoid bankruptcy and job losses. However, this paper is in line with the current literature that attributes greater weight to factors related 
to business management as the most important causes of the zombie phenomenon. This can be attributed to the delay in the implementation of best practices in business management and other characteristics of Mexican companies such as the concentration of ownership or the presence of family firms.

In this sense, the empirical antecedents are not consistent with the effect of strategic behavior. The result of this paper coincides with those of Fukuda and Nakamura (2011) and Urionabarrenetxea et al. (2016). They predicted that innovative and proactive companies are the ones that become zombie companies, maybe because these organizations' projects involve a higher degree of uncertainty (Jermias, 2008; Simerly \& Li, 2000). In addition, OrtizVillajos and Sotoca (2018) proved that the bankruptcy risk in these companies is higher.

One characteristic to consider is that in the Latin American region, the promotion of innovation in companies is seen by institutions as an engine of development and social equity. Thus, the implementation of instruments that encourage and help carry out these actions is highly probable (Albornoz, 2013; Brito \& Vasconcelos, 2006). Lin and Chang (2009) argue that in some cases subsidies are awarded for carrying out innovation activities. This reinforces the idea of strategic behavior that is not in accordance with the company's capabilities, or failure to implement the business strategy.

The other set of factors studied relates to the industry where the companies operate. In this regard, it was found that barriers to entry have an opposite effect than expected: more barriers negatively impact zombie companies. When it is easy to enter a market, there will be more zombie companies. To understand "why," one can analyze the role of institutions in Latin America. On many occasions, they promote investment by economic agents in specific industries by offering benefits or facilities to carry out the activity, in other words, by artificially reducing barriers to entry and allowing the entry of less capable or committed firms (Lin \& Chang, 2009). These policies force entrepreneurial activity into industries that would not usually be predominant in the economy, giving priority to sectors where intensive use of capital is necessary and not precisely where there is a productive specialization (Lin \& Chang, 2009; Sunkel, 2009).

On the other hand, market competitiveness behaved just as the literature anticipated: competitiveness negatively affects zombie companies. However, the measure used showed additional information; it was found that companies concentrate or monopolize the market, limiting other firms from competing against them. This behavior is somewhat similar to the "fat and happy" companies described by Boulding and Staelin (1993) because Mexican zombie companies dominate their respective markets and create a comfortable position.

Finally, another aspect to highlight are the types of sectors in which the zombie companies are located (for example, construction companies, extractors of raw materials, telecommunications, and energy companies), which are key industries for the country's economy as they contribute to the development of infrastructure, offer the necessary services for the population (construction, energy, real estate), and are intermediaries or complementary providers. Therefore, it is essential to keep these companies active.

Based on the above, the zombie firms in America Latina lead me to believe that, first, they are not necessarily negative agents for economies (though a study would have to measure the impact these companies generate on other organizations). However, they are necessary for the existence of markets that offer what society demands in the form of goods and services. On the other hand, there are indications that the figure of a zombie company is a mechanism acquired voluntarily to carry out operations or because it is advantageous for it to survive.

\section{Conclusions}

The purpose of the study was to analyze the effect of business strategy and industry characteristics on zombie companies in Mexico, which was proposed by the previous literature, in which industry characteristics have been analyzed above all. Regarding business strategy, traditionally isolated elements have been used regarding operational actions and not a more complete vision of business strategy. To meet the main objective, companies listed on the BMV were used and, through a panel data analysis, the empirical results were obtained. This research is one of the pioneers in studying these companies in Latin America; therefore it contributes to the literature and the debate on management in the region.

Among the main findings, I can first mention that the study of zombie companies must be approached from the different perspectives of administrative sciences since the results show a difference with respect to zombie companies from other countries. The fact that a strategy encourages zombie behavior may be due to poor strategic 
implementation or a deficit in the implementation of the strategy. It may also be due to the action of leaders, which suggests an agency problem. For example, it is believed that the type of strategy per se does not give a specific result. However, the process that it implies can lead to failure. What has been said so far supports the idea that zombie companies are independent of the macroeconomic situation, as was originally believed.

On the other hand, the role of institutions, mentioned in the discussion a couple of times, is an element that can contribute to understanding the phenomenon. For this reason, it represents another recommended path to continue the research. The proposed research lines show that zombie companies as a research topic is a "greenfield" and of interest for administrative sciences, in order to understand the diversity of companies and the forms and behaviors that these economic units acquire to compete or survive.

To close the paper, it is necessary to mention that the main limitation of the study is that the sample of companies used does not represent the entire Mexican business population. Only companies with specific characteristics (registered with the BMV) were studied. For this reason, a greater diversity of companies should be analyzed to complement the results obtained in this study. Also, as a future line of research, I propose studying zombie companies from different theoretical perspectives of administrative sciences, such as institutional isomorphism (due to the role of the industry in zombie companies), as well as the inclusion of variables such as corporate governance. Finally, the study must be replicated in other countries in the region in order to extend the understanding of zombie companies in Latin America.

\section{References}

AILAWADI, K. L., FARRIS, P. W., \& PARRY, M. E. (1999). Market share and ROI: Observing the effect of unobserved variables. International Journal of Research in Marketing, 16(1), 17-33. doi: 10.1016/S01678116(98)00012-3

ALABEDE, J. O. (2018). Economic freedom and tax revenue performance in sub-Saharan Africa. Journal of Financial Reporting and Accounting, 16(4), 610-638. doi: 10.1108/JFRA-04-2017-0024
ALBERTOS, J. F., \& KUO, A. (2018). The structure of business preferences and eurozone crisis policies. Business and Politics, 20(2), 165-207. doi: 10.1017/bap.2017.35

ALBORNOZ, M. (2013). Innovación, equidad y desarrollo latinoamericano. Isegoria, (48), 111-126. doi: 10.3989/ isegoria.2013.048.06

AMATO, M., \& FANTACCI, L. (2016). Failures on the market and market failures: A complementary currency for bankruptcy procedures. Cambridge Journal of Economics, 40(5), 1377-1395. doi: 10.1093/cje/bew029

ANWAR, J., \& HASNU, S. A. F. (2016). Business strategy and firm performance: A multi-industry analysis. Journal of Strategy and Management, 9(9), 361-382. doi: 10.1108/ JSMA-09-2015-0071

ANWAR, J., \& HASNU, S. A. F. (2017). Strategyperformance relationships: A comparative analysis of pure, hybrid, and reactor strategies. Journal of Advances in Management Research, 14(3), 446-465. doi: 10.1108/ JAMR-07-2016-0056

BAILEY, D., \& KATZ, J. N. (2011). Implementing panel-corrected standard errors in R: The PCSE Package. Journal of Statistical Software, 42(CS1), 1-11. doi: 10.18637/jss.v042.c01

BAIN, J. (1968). Industrial organization. (2nd ed.). New York: John Wiley and Sons.

BECK, N., \& KATZ, J. N. (1995). What to do (and not to do) with time-series cross-section. American Political Science Review, 89, (3), 634-647. doi: 10.2307/2082979

BENTLEY, K. A., OMER, T. C., \& SHARP, N. Y. (2013). Business strategy, financial reporting irregularities, and audit effort. Contemporary Accounting Research, 30(2), 780-817. doi: 10.1111/j.1911-3846.2012.01174.x

BOULDING, W., \& STAELIN, R. (1990). Environment, market share, and market power. Management Science, 36(10), 1160-1177. doi: 10.1287/mnsc.36.10.1160

BOULDING, W., \& STAELIN, R. (1993). A Look on the cost side: Market share and the competitive environment. Marketing Science, 12(2), 144-166. doi: $10.1287 / \mathrm{mksc} .12 .2 .144$ 
BRITO, L. A. L., \& VASCONCELOS, F. C. de. (2006). Las empresas latinoamericanas: Factores determinantes de su desempeño. Retrieved from https://repositorio.cepal. org/handle/11362/1947

BROZ, T., \& RIDZAK, T. (2017). Lending activity and credit supply in Croatia during the crisis. Journal of Policy Modeling, 39(6), 1102-1116. doi: 10.1016/j. jpolmod.2017.08.004

CABALLERO, R. J., HOSHI, T., \& KASHYAP, A. K. (2008). Zombie lending and depressed restructuring in Japan. American Economic Review, 98(5), 1943-1977. doi: 10.1257/aer.98.5.1943

CABrera, G., CORONADO, S., ROJAS, O., \& ROMERO-MEZA, R. (2018). A Bayesian approach to model changes in volatility in the Mexican stock exchange index. Applied Economics, 50(15), 1716-1724. doi: 10.1080/00036846.2017.1374536

CAMERON, A., \& TRIVEDI, P. (2010). Microeconometrics using stata (Ed. rev.). Texas: Stata Press Publication.

CAMPA, D., \& CAMACHO, M. (2014). Earnings management among bankrupt non-listed firms: Evidence from Spain. Revista Española de Financiación y Contabilidad, 43(1), 3-20. https://doi.org/10.1080/02102412.2014 .890820

CAVES, R. E. (1980). Industrial organization, corporate strategy and structure. Journal of Economic Literature, 18(1), 64-92. doi: 10.1007/978-1-4899-7138-8_16

CERVANTES, M., MONTOYA, M. A., \& CUETO, D. C. (2014). Momentum Effect on the Mexican Stock Exchange (SSRN Scholarly Paper ID 2392467). Retrieved from Social Science Research Network. https://papers. ssrn. com/abstract $=2392467$

CETORELLI, N., \& PERISTIANI, S. (2013). Prestigious stock exchanges: A network analysis of international financial centers. Journal of Banking \& Finance, 37(5), 1543-1551. doi: 10.1016/j.jbankfin.2012.06.011

CHRISTMANN, P., DAY, D., \& YIP, G. S. (1999). The relative influence of country conditions, industry structure, and business strategy on multinational corporation subsidiary performance. Journal of International Management, 5(4), 241-265. doi: 10.1016/S1075-4253(99)00015-0

COLLARD-WEXLER, A. (2014). Mergers and sunk costs: An application to the ready-mix concrete industry. American Economic Journal: Microeconomics, 6(4), $407-$ 447. doi: 10.1257/mic.6.4.407

COOL, K., DIERICKX, I., \& JEMISON, D. (1989). Business strategy, market structure and risk-return relationships: A structural approach. Strategic Management Journal, 10(6), 507-522. doi: 10.1002/smj.4250100602

DEMSETZ, H. (1973). Industry structure, market rivalry, and public policy. Journal of Law and Economics, 16(1), 1-9. doi: 10.1086/466752

EDELING, A., \& HIMME, A. (2018). When does market share matter? New empirical generalizations from a meta-analysis of the market share-performance relationship. Journal of Marketing, 82(3), 1-24. doi: 10.1509/jm.16.0250

ELLICKSON, P. B. (2015). Market structure and performance. In J. D. Wright (Ed.), International Encyclopedia of the Social \& Behavioral Sciences (2 ${ }^{\text {nd }}$ ed., Vol.14, pp. 549-554). Oxford: Elsevier.

EVANS, J. D., \& GREEN, C. L. (2000). Marketing strategy, constituent influence, and resource allocation: An application of the miles and snow typology to closely held firms in chapter 11 bankruptcy. Journal of Business Research, 50(2), 225-231. doi: 10.1016/S0148-2963(99)00036-3

FASSLER, K. W., \& FLORES VARGAS, D. R. (2016). Determinants of firms' ownership concentration in Mexico. Contaduria y Administracion, 61(2), 224-242. doi: $10.1016 /$ j.cya.2015.05.015

FUKUDA, S.-I., \& NAKAMURA, J.-I. (2011). Why did "zombie" firms recover in Japan? World Economy, 34(7), 1124-1137. doi: 10.1111/j.1467-9701.2011.01368.x

GALLAGHER, D. R., IGNATIEVA, K., \& MCCULLOCH, J. (2014). Industry concentration, excess returns and innovation in Australia. Accounting \& Finance, 55(2), 443-466. doi: 10.1111/acfi.12074 
GHEMAWAT, P. (2002). Competition and business strategy in historical perspective. Business History Review, 76(1), 37-74. doi: 10.2307/4127751

GUJARATI, D. N., \& PORTER, D. C. (2004). Econometria básica (4a ed.). São Paulo McGraw Hill.

GUTIÉRREZ RODRÍGUEZ, R. E., \& ALMANZA, C. A. (2016). Una aproximación a la caracterización competitiva de los sectores productivos industrial y floricultor del municipio de Madrid Cundinamarca, Colombia. Suma de Negocios, 7(16), 82-93. doi: 10.1016/j. sumneg.2016.02.006

HALL, D. J., \& SAIAS, M. A. (1980). Strategy follows structure! Strategic Management Journal, 1(2), 149-163. doi: 1002/smj.4250010205

HAMBRICK, D. C. (2003). On the staying power of defenders, analyzers, and prospectors. Academy of Management Executive, 17(4), 115-118. doi: 10.5465/ AME.2003.11851883

HIGGINS, D., OMER, T. C., \& PHILliPS, J. D. (2015). The Influence of a firm's business strategy on its tax aggressiveness. Contemporary Accounting Research, 32(2), 674-702. doi: 10.1111/1911-3846.12087

HO, P. H. K. (2015). Analysis of competitive environments, business strategies, and performance in Hong Kong's construction industry. Journal of Management in Engineering, 32(2). doi: 10.1061/(ASCE)ME.1943-5479.0000399

HOSHI, T. (2006). Economics of the living dead. Japanese Economic Review, 57(1), 30-49. doi: 10.1111/j.14685876.2006.00354.x

HOYOS, R. E. de., \& SARAFIDIS, V. (2006). Testing for cross-sectional dependence in panel-data models. Stata Journal, 6(4), 482-496. doi: 10.1177/1536867X0600600403

HSU, S.-K., TSAI, M.-F., \& YANG, C.-H. (2008). Market structure, external exposure and industry profitability: Evidence from Taiwan. International Economic Journal, 22(2), 201-214. doi: 10.1080/10168730802079805

IMAI, K. (2016). A panel study of zombie SMEs in Japan: Identification, borrowing and investment behavior. Journal of the Japanese and International Economies, 39, 91-107. doi: 10.1016/j.jjie.2015.12.001
IWAISAKO, T., FUKUOKA, C., \& KANOU, T. (2013). Debt restructuring of Japanese corporations: efficiency of factor allocations and the debt-labor complementarity. Hitotsubashi Journal of Economics, 54(1), 119-135. Retrieved from https://www.jstor.org/stable/43296264

JACOBSON, R. (1988). Distinguishing among competing theories of the market share effect. Journal of Marketing, 52(4), 68-80. doi: 10.2307/1251634

JERMIAS, J. (2008). The relative influence of competitive intensity and business strategy on the relationship between financial leverage and performance. The British Accounting Review, 4O(1), 71-86. doi: 10.1016/j.bar.2007.11.001

JIANG, X., LI, S., \& SONG, X. (2017). The mystery of zombie enterprises - "stiff but deathless". China Journal of Accounting Research, 10(4), 341-357. doi: 10.1016/j. cjar.2017.08.001

JUÁREZ, G. L., DAZA, A. S., \& GONZÁLEZ, J. Z. (2015). La crisis financiera internacional de 2008 y algunos de sus efectos económicos sobre México. Contaduría y Administración, 60(Suppl. 2), 128-146. doi: 10.1016/j. cya.2015.09.011

KEIL, J. (2017). The trouble with approximating industry concentration from Compustat. Journal of Corporate Finance, 45(C), 467-479. doi: 10.1016/j.jcorpfin.2017.05.019

KEIL, J. (2018). Is There a Causal Effect of Concentration on Persistent Profitability Differentials? (SSRN Scholarly Paper ID 2879163). Retrieved from Social Science Research Network. https://papers.ssrn.com/abstract=2879163

KEMME, D. M., \& KOLEYNI, K. (2017). Exchange rate regimes and welfare losses from foreign crises: The impact of the US financial crisis on Mexico. Review of International Economics, 25(1), 132-147. doi: 10.1111/ roie. 12259

KHAN, H. H., AHMAD, R. B., \& CHAN, S. G. (2018). Market structure, bank conduct and bank performance: Evidence from ASEAN. Journal of Policy Modeling, 40(5), 934-958. doi: 10.1016/j.jpolmod.2018.02.001

KHAN, H. H., AHMAD, R. B., \& GEE, C. S. (2016). Market structure, financial dependence and industrial growth: Evidence from the banking industry in emerging 
Asian economies. PLOS ONE, 11(8), e0160452. doi: 10.1371/journal.pone.0160452

KIMENYI, M. S., LEE, J., \& SHUGHART, W. F. II. (1990). Price-cost margins and industry structure in developing countries: The case of Korea*. Bulletin of Economic Research, 42(3), 197-210. doi: 10.1111/j.14678586.1990.tb00670.x

LEE, H. J. (2017). Creative Destruction Mechanism of Korean Industry from the Perspective of Industrial Dynamics. Retrieved from http://s-space.snu.ac.kr/handle/10371/136840

LEE, Y.-C., \& YANG, Y.-H. (2016). Analysis of industrial structure, firm conduct and performance: A case study of the textile industry. Autex Research Journal, 16(2), 35-42. doi: 10.1515/aut-2015-0017

LEVIN, R. C., COHEN, W. M., \& MOWERY, D. C. (1985). R \& D Appropriability, Opportunity, and Market Structure: New Evidence on Some Schumpeterian Hypotheses. The American Economic Review, 75(2), 20-24. Retrieved from https://www.jstor.org/stable/1805564

LI, D., \& LIU, J. (2009). Determinants of Financial Distress of ST and PT Companies: A Panel Analysis of Chinese Listed Companies (SSRN Scholarly Paper ID 1341795). Retrieved from Social Science Research Network. https:// papers.ssrn.com/abstract $=1341795$

LI, Y., NIE, D., ZHAO, X., \& LI, Y. (2017). Market structure and performance: An empirical study of the Chinese solar cell industry. Renewable and Sustainable Energy Reviews, 70, 78-82. doi: 10.1016/j.rser.2016.11.064

LIN, J., \& CHANG, H.-J. (2009). Should industrial policy in developing countries conform to comparative advantage or defy it? A debate between Justin Lin and Ha-Joon Chang. Development Policy Review, 27(5), 483502. doi: 10.1111/j.1467-7679.2009.00456.x

MA, M., WENG, J., \& YU, L. (2015). Market size, scale economies, and tourism market structure: A case of historic water town tourism in China. Tourism Management, 49, 119-137. doi: 10.1016/j.tourman.2015.02.014

MAICAN, F. G., \& ORTH, M. (2018). Entry regulations, welfare, and determinants of market structure. International Economic Review, 59(2), 727-756. doi: 10.1111/iere.12286
MAQUiEIRA, C. P., PREVE, L. A., \& SARRIAALLENDE, V. (2012). Theory and practice of corporate finance: Evidence and distinctive features in Latin America. Emerging Markets Review, 13(2), 118-148. doi: 10.1016/j. ememar.2011.11.001

MARTIN. (1983). Market, Firm, and Economic Performance: An empirical analysis (Working paper No. 84). Retrieved from https://www.ftc.gov/system/files/documents/reports/ market-firm-economic-performance-empirical-analysis/ wp084.pdf

MASON, E. S. (1939). Price and production policies of large-scale enterprise. The American Economic Review, 29(1), 61-74. Retrieved from https://www.jstor.org/ stable/1806958

MCGOWAN, M. A., ANDREWS, D., \& MILLOT, V. (2017a). Insolvency regimes, zombie firms and capital reallocation [OECD Working Papers No. 1399]. Retrieved from Organisation for Economic Co-operation and Development. https://www.oecd-ilibrary.org/ docserver/5a16beda-en.pdf?expires $=1624981811 \& \mathrm{id}=\mathrm{i}$ $\mathrm{d} \&$ accname $=$ guest $\&$ checksum $=85 \mathrm{~F} 15 \mathrm{FD} 185 \mathrm{CA06AA}$ 252E98330FB54C99

MCGOWAN, M. A., ANDREWS, D., \& MILLOT, V. (2016b). The Walking Dead? Zombie firms and Productivity Performance in OECD countries. [OECD Working Papers No.1372] Retrieved from Organisation for Economic Co-operation and Development https://www.oecd.org/ economy/growth/The-Walking-Dead-Zombie-Firmsand-Productivity-Performance-in-OECD-Countries.pdf

MCGOWAN, D. (2014). Do entry barriers reduce productivity? Evidence from a natural experiment. Economics Letters, 125(1), 97-100. doi: 10.1016/j. econlet.2014.08.014

MILES, R. E., SNOW, C. C., MEYER, A. D., \& COLEMAN, H. Jr. (1978). Organizational strategy, structure, and process. Academy of management review. Academy of Management, 3(3), 546-562. Scopus. doi: 10.5465/AMR.1978.4305755

MILLO, G. (2017). Robust standard error estimators for panel models: A unifying approach. Journal of Statistical Software, 82(3), 1-27. doi: 10.18637/jss.v082.i03 
MOHAMMED, N., ISMAIL, A. G., \& MUHAMMAD, J. (2015). Evidence on market concentration in Malaysian dual banking system. Procedia - Social and Behavioral Sciences, 172, 169-176. doi: 10.1016/j.sbspro.2015.01.351

MORENO-LÁZARO, J. (2015). The stock exchange the state and economic development in Mexico 19321976*. Revista de Historia Economica - Journal of Iberian and Latin American Economic History, 33(2), 321-350. doi: $10.1017 / S 021261091500018 \mathrm{X}$

MORENO-LÁZARO, J. (2017). La Bolsa de Valores de México durante el porfiriato y la revolución, 1885-1934. América Latina en la Historia Económica, 24(1), 98-139. doi: 10.18232/alhe.v24i1.729.

MUELLER, D. (1983). The determinants of persistent profits. An Empirical Study. Bureau of Economics, U.S. Federal Trade Commission. https://www.ftc.gov/sites/ default/files/documents/reports/determinants-persistentprofits/198306determinantsprofits.pdf

NAKAMURA, J.-I., \& FUKUDA, S.-I. (2013). What happened to "zombie" firms in Japan?: Reexamination for the lost two decades. Global Journal of Economics, 02(02), 1-18. doi: 10.1142/S2251361213500079

NOGUEIRA, M. Á., FERNÁNDEZ-LÓPEZ, S., CALVO, N., \& RODEIRO-PAZOS, D. (2018). Firm characteristics, financial variables and types of innovation: Influence in Spanish firms' survival. International Journal of Entrepreneurship and Innovation Management, 22(1-2), 57-79. doi: 10.1504/IJEIM.2018.089714

NOMAN, A. H. M., GEE, C. S., \& ISA, C. R. (2017). Does competition improve financial stability of the banking sector in ASEAN countries? An empirical analysis. PLOS ONE, 12(5), e0176546. doi: 10.1371/ journal.pone. 0176546

OHLSON, J. A. (1980). Financial ratios and the probabilistic prediction of bankruptcy. Journal of Accounting Research, 18(1), 109-131. doi: 10.2307/2490395

ORTIZ-VILLAJOS, J. M., \& SOTOCA, S. (2018). Innovation and business survival: A long-term approach. Research Policy, 47(8), 1418-1436. doi: 10.1016/j. respol.2018.04.019
PEREIRA, E. T., \& JARDIM, C. (2013). Corporate bankruptcy of Portuguese firms. Zagreb International Review of Economics and Business, 16(2), 39-56. Retrieved from https://www.researchgate.net/publication/258763924_ Corporate_Bankruptcy_of_Portuguese_Firms

PESARAN, M. H. (2004). General Diagnostic Tests for Cross Section Dependence in Panels (SSRN Scholarly Paper ID 572504). Retrieved from Social Science Research Network. https://papers.ssrn.com/abstract=572504

PORTER, M. E (1980). Competitive Strategy: Techniques for Analyzing Industries and Competitors. New York: Free Press.

PORTER, M. E. (1996). What Is Strategy? Harvard Business Review, 74(6), 61-78. Retrieved from https:// www.hbs.edu/faculty/Pages/item.aspx?num=10698

REED, W. R., \& YE, H. (2011). Which panel data estimator should I use? Applied Economics, 43(8), 9851000. doi: $10.1080 / 00036840802600087$

REN, C. R., HU, Y., \& CUI, T. H. (2018). Responses to rival exit: Product variety, market expansion, and preexisting market structure. Strategic Management Journal, 40(2). doi: $10.1002 / \mathrm{smj} .2970$

RUMELT, R. P., SCHENDEL, D., \& TEECE, D. J. (1991). Strategic management and economics. Strategic Management Journal, 12(S2), 5-29. doi: 10.1002/ smj.4250121003

SCHIVARDI, F., \& VIVIANO, E. (2011). Entry barriers in retail trade. The Economic Journal, 121(551), 145-170. doi: 10.1111/j.1468-0297.2009.02348.x

SCHMALENSEE, R. (1989). Chapter 16 Inter-industry studies of structure and performance. In R. Schmalensee, \& R. D. Willig (Eds.), Handbook of Industrial Organization (Vol. 2, pp. 951-1009). Amsterdam: Elsevier.

SHAPIRO, C. (1989). The Theory of Business Strategy. The RAND Journal of Economics, 20(1), 125-137. doi: $10.2307 / 2555656$

SHEEL, A. (2016). SCP-relevance and class-effect in performance - A comparative analysis of restaurants and petroleum firms. International Journal of Hospitality Management, 52, 33-45. doi: 10.1016/j.ijhm.2015.09.012 
SHEN, G., \& CHEN, B. (2017). Zombie firms and over-capacity in Chinese manufacturing. China Economic Review, 44, 327-342. doi: 10.1016/j.chieco.2017.05.008

SIMERLY, R. L., \& LI, M. (2000). Environmental dynamism, capital structure and performance: A theoretical integration and an empirical test. Strategic Management Journal, 21(1), 31-49. doi: 10.1002/(SICI) 1097-0266(200001)21:1<31::AIDSMJ76>3.0.CO;2-T

SMITH, K. G., GUTHRIE, J. P., \& CHEN, M.-J. (1986). Miles and snow's typology of strategy, organizational size and organizational performance. Academy of Management Proceedings, 1986(1), 45-49. doi: 10.5465/ ambpp.1986.4978509

STIEGERT, K. W., WANG, S.-S., \& ROGERS, R. T. (2009). Structural change and market power in the US food manufacturing sector. Agribusiness, 25(2), 164-180. doi:10.1002/agr.20193

SUNKEL, O. (2009). En busca del desarrollo perdido. Problemas del Desarrollo. Revista Latinoamericana de Economía, 37(147). doi: 10.22201/iiec.20078951e.2006.147.7632

SZYMANSKI, D. M., BHARADWAJ, S. G., \& VARADARAJAN, P. R. (1993). An analysis of the market share-profitability relationship. Journal of Marketing, 57(3), 1-18. doi: 10.2307/1251851

TAN, Y., HUANG, Y., \& WOO, W. T. (2016). Zombie firms and the crowding-out of private investment in China. Asian Economic Papers, 15(3), 32-55. doi: 10.1162/ ASEP_a_00474

TONG, Y., \& SALADRIGUES, R. (2018). The predictability of financial, accounting-based, and industrial factors on the success of newly incorporated Spanish firms. Intangible Capital, 14(1), 127-145. doi: 10.3926/ic.1106

UCHIDA, H., MIYAKAWA, D., HOSONO, K., ONO, A., UCHINO, T., \& UESUGI, I. (2015). Financial shocks, bankruptcy, and natural selection. Japan and the World Economy, 36, 123-135. doi: 10.1016/j. japwor.2015.11.002

URIONABARRENETXEA, S., GARCIA-MERINO, J. D., SAN-JOSE, L., \& RETOLAZA, J. L. (2018). Living with zombie companies: Do we know where the threat lies? European Management Journal. doi: 10.1016/j.emj.2017.05.005

URIONABARRENETXEA, S., SAN-JOSE, L., \& RETOLAZA, J.-L. (2016). Negative equity companies in Europe: Theory and evidence. Business: Theory and Practice, 17(4), 307-316. doi: 10.3846/btp.17.11125

VARADARAJAN, R., \& KAUR, R. (2018). Doing well by doing good innovations: Alleviation of social problems in emerging markets through corporate social innovations. Journal of Business Research, 86, 225-233. doi: 10.1016/j. jbusres.2017.03.017

VICENTE-LORENTE, J. D. (2001). Specificity and opacity as resource-based determinants of capital structure: Evidence for Spanish manufacturing firms. Strategic Management Journal, 22(2), 157-177. doi: 10.1002/1097-0266(200101)22:2<157::AIDSMJ152>3.0.CO;2-2

WERNERFELT, B., \& MONTGOMERY, C. (1988). Tobin's q and the importance of focus in firm performance. The American Economic Review, 78(1), 246-250.

WU, P., GAO, L., \& GU, T. (2015). Business strategy, market competition and earnings management: Evidence from China. Chinese Management Studies, 9(3), 401-424. doi: 10.1108/CMS-12-2014-0225

YAHYA, F., \& GHAZALI, Z. B. (2017). Effectiveness of board governance and dividend policy as alignment mechanisms to firm performance and CEO compensation. Cogent Business \& Management, 4(1), 1-20. doi: 10.1080/23311975.2017.1398124

YAO, M., SONG, C., \& SONG, Z. (2018). State ownership, political connections and entry barriers: Evidence from China. Applied Economics Letters, 25(17), 12501254. doi: 10.1080/13504851.2017.1414928 


\section{Appendix}

\section{Research measures}

For the zombie firms the method developed by Hoshi (2006, p.36), known as EIR, was used. First, I calculated the hypothetical benchmark interest payment $\left(\mathrm{R}^{*}\right)$ as follows:

$$
R_{i, t}^{*}=\left(r s_{t-1} \cdot B S_{i, t-1}\right)+\left(\left(\frac{1}{5} \sum r l_{t, j}\right) \cdot B L_{i, t-1}\right)
$$

BS represents the short-term liabilities minus accounts payable and taxes payable; BL is the long-term liabilities; rs represents the average short-term interest rate; $\mathrm{rl}$ is the average long-term interest rate (the interest rate taken as a reference was CETES, which are debt instruments issued by the government that have a preferential cost). Afterwards, it is necessary to compare $\mathrm{R}^{*}$ with respect to the real interest payment $(\mathrm{R})$ using the following formula:

$$
E I R=\frac{R_{i, j}-R_{i, j}^{*}}{\frac{R_{i, j}+R^{*}{ }_{i, j}}{2}}
$$

EIR takes values between -2 and 2, where zombie companies fall on the negative side, while non-zombie companies are on the positive side.

For strategic behavior, the scoring method is applied (Evans \& Green, 2000; Smith et al., 1986), based on financial information. In this paper, strategic behavior is formed of four measures, as described in Table A1.

Table A1.

\begin{tabular}{|c|c|c|}
\hline Dimension & Measure & Interpretation \\
\hline Orientation towards innovation (OTI) & $\begin{array}{c}\text { Marketing, maintenance, and } \\
\text { administrative expense } \\
\text { Sales }\end{array}$ & $\begin{array}{l}\text { High value for proactive behavior / Low } \\
\text { value for defensive behavior. }\end{array}$ \\
\hline Production efficiency (PE) & $\frac{\text { Sales cost }}{\text { Sales }}$ & $\begin{array}{l}\text { High value for proactive behavior / Low } \\
\text { value for defensive behavior. }\end{array}$ \\
\hline Sales growth rate (SGR) & $\frac{\text { Initial sales value }}{\text { Final sales value }} \frac{1}{\# \text { of years }}$. & $\begin{array}{l}\text { High value for proactive behavior / Low } \\
\text { value for defensive behavior. }\end{array}$ \\
\hline Capital intensity rate (CIR) & $\frac{\text { Value of property, plant, and equipment }}{\text { Total assets }}$ & $\begin{array}{c}\text { Low value for proactive behavior / High } \\
\text { value for defensive behavior. }\end{array}$ \\
\hline
\end{tabular}

\section{Dimensions that define strategic behavior.}

Note. Adapted from Anwar and Hasnu (2016, 2017); Bentley et al. (2013); Hambrick (2003); Higgins et al. (2015).

Each company was ranked from weakest to strongest for each indicator using a quintile ranking. Finally, points between 0 and 4 were awarded according to the quintile achieved ( 0 for the lowest quintile and 4 for the highest), where the score is inverse for CIR.

For market competitiveness, relative market share it used. Market share is a measure that shows the share that each company represents in a particular sector.

Market share $=\frac{X i j}{X j}$ 
$\mathrm{Xij}$ represent the sales of firm $\mathrm{i}$ in industry $\mathrm{j}$ and $\mathrm{Xj}$ means the sales of industry $\mathrm{j}$. The result is multiplied by -1 because the market share is an inverse measure for market competitiveness; in other words, a higher (lower) concentration implies lower (higher) competitiveness.

For barriers to entry, the measure selected is the level of capital investment necessary to compete. The following formula was used to calculate the variable:

$$
\text { Investment cost }=\frac{(C C i j)}{(P i j)}
$$

CCij represents the stockholders' equity of company $\mathrm{i}$ in industry $\mathrm{j}$ and Pij is the production or sales value of company $\mathrm{i}$ in industry $\mathrm{j}$.

\section{Financial support:}

Name of the funding agency /OR/ There are no funding agencies to report.

\section{Conflicts of interest:}

The authors have no conflict of interest to declare.

\section{Copyrights:}

RBGN owns the copyrights of this published content.

\section{Plagiarism analysis:}

RBGN performs plagiarism analysis on all its articles at the time of submission and after approval of the manuscript using the iThenticate tool.

\section{Authors:}

1. Manuel Humberto De la Garza Cárdenas, School of Commerce and Administration, Autonomous University of Tamaulipas, Ciudad Victoria, Tamaulipas, Mexico.

mdelagarza@docentes.uat.edu.mx

\section{Authors' Contributions:}

$1^{\text {st }}$ author: Definition of research problem; Development of hypotheses or research questions (empirical studies); Development of theoretical propositions (theoretical work); Definition of methodological procedures; Data Collection; Literature review; Statistical analysis; Analysis and interpretation of data; Critical revision of the manuscript; Manuscript writing. 